\title{
AZF-DELETION - ONE OF THE GENETIC CAUSES OF MALE INFERTILITY
}

\author{
V.P. Stus ${ }^{1}$, L.I. Padalko ${ }^{2}$, M.Y. Polion ${ }^{1}$ \\ ${ }^{1}$ SI "Dnipropetrovsk Medical Academy MOH of Ukraine" \\ ${ }^{2}$ MI "Dnipropetrovsk Regional Perinatal Center with Hospital” DRC
}

Detection of genetic abnormalities in patients with disorders of the reproductive function can improve medical diagnostic and consultative and diagnostic help couples with infertility and improve measures aimed at the prevention of infertility [2]. Thus, the causes of infertility can be chromosomal abnormalities micro structural reorganization and gene mutations that may lead to a breach of sex determination, differentiation and / or development of the reproductive system, its hormonal dysregulation, disruption of spermatogenesis and / or sperm function [5].

The possibility of investigating the causes of infertility in men in the last decade have increased significantly thanks to the human genome, sequenced Y-chromosome and the introduction of modem molecular techniques in the practice of medicine, which allowed to establish one of the causes of reproductive disorders in men $-\mathrm{Y}$-chromosome microdeletions. To organize and understand the genetic abnormalities Y-chromosomes and their role in the development of male infertility should consider the stricture of the Y-chromosome (Fig. 1).

$\mathrm{Y}$-chromosome is less than $1 \%$ of the genome and is the only chromosome that is always in the haploid state. Has a short arm (p-arm) and long arm (q-arm). Identify the following areas of $\mathrm{Y}$ chromosome:

- Pseudoautosomic areas of the telomeric regions of the p-and $\mathrm{q}$-arm $\mathrm{Y}$-chromosome;

- Euchromatic region of the short arm - Yrl 11

- Euchromatic region of the proximal long arm - Yql 12;

- Heterochromatic region of the distal part of the long arm - Yq12;

- Area pericentrometric heterochromatin.

The role of the delitions of the long arm of Y-chromosome in the etiology of the disorders of spermatogenesis and male infertility was described in 1976. Suggested the presence of the site in the locus Yq11, required for spermatogenesis, which was called azoospermia factor (azoospermia factor) [13].

In the proximal part of the euchromatic region of the long arm (Yql 1) mapped genes that are part

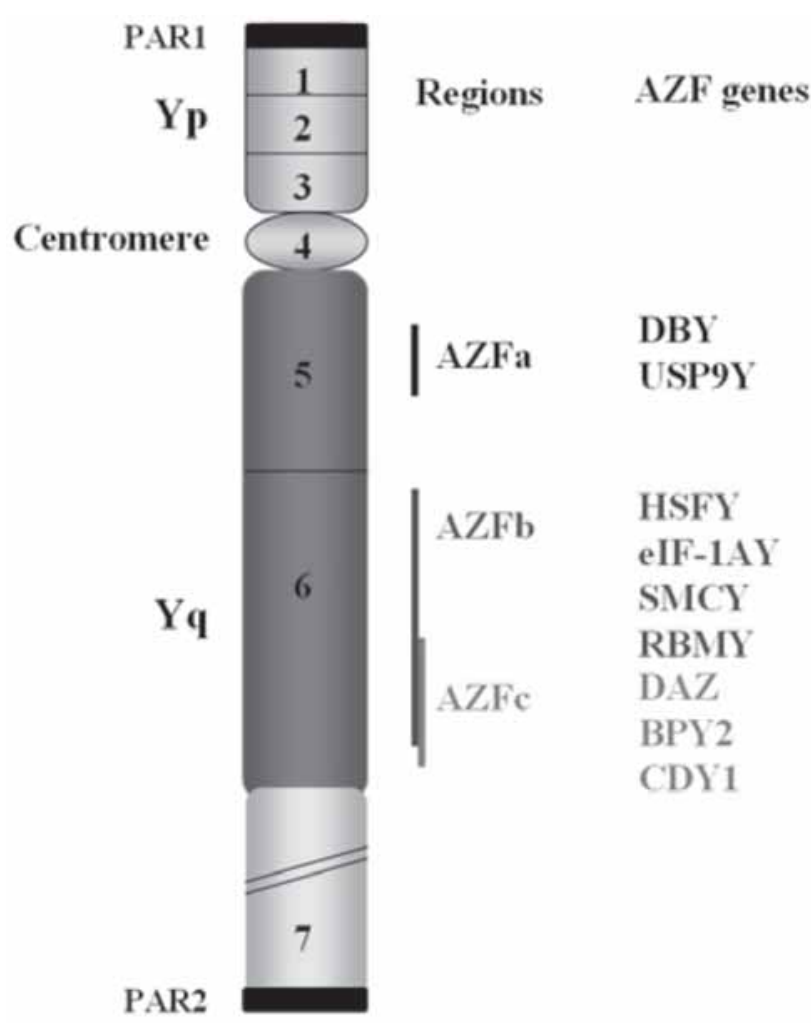

Fig. 1. Schematic representation of the $Y$ chromosome showing the 7 deletion intervals. The three $A Z F$ regions and the candidate AZF genes are indicated. PseudoAutosomial Region 1 and 2 (PAR1, PAR2); Yp: short arm of the $Y$ chromosome; Yq: long arm of the $Y$

of the locus AZF. AZF locus is divided into three regions - AZFa, AZFb, AZFc, each of which contains a candidate gene, mutations in which lead to varying degrees of disruption of spermatogenesis.

AZFa subregion contains three genes: USP9Y (ubliquitin-specific protease 9, Y-chromosome), DBY (dead-box / H box3, Y-linked), UTY (ubiquitously transcribed tetratricopeptide repeat gene on $\mathrm{Y}$ chromosome). Absence or USP9Y DBY leads to disruption of spermatogenesis [4].

AZFb subregion contains two genes: E1F1AY (eukaryotic translation initiation factor 1A, Ylinked) and RBMY (RNA-binding motif protein, Y-chromosome). Deletion of a copy or copies of the gene RBMY may be associated with azoospermia or oligozoospermia [1]. 
AZFc subregion contains 8 genes: DAZ (deleted in azoospermia), BPY2 (Testis-specific basic protein Y-linked-2), CDY1 (chromo-domain protein, Y-chromosome, 1), CSPG4LYP2 (chondroitin sulfate proteoglycan 4-like, Y-linked pseudogene 2), GOLGA2LY (golgi autoantigen, golgin subfamily A,2-like, Y-linked), TTY3 (testis-specific transcript, Y-linked-3) and TTY4 (testis- specific transcript, Y-linked-3).

Deletions in the AZF locus may be complete (full delete one or more AZF region) and partial (deletions are not fully capture one of the three regions).

Microdeletions spanning the AZF region or sub-regions $\mathrm{AZFa}, \mathrm{AZFb}, \mathrm{AZFb}$, c lead to a complete absence of healthy sperm. In $50 \%$ of patients with a deletion entirely exciting AZFc-region, it is possible to obtain sperm suitable for artificial insemination. Low sperm count and limited mobility do not provide physiological fertilization. Therefore, in vitro fertilization is carried out by the introduction of sperm into the cytoplasm of the oocyte (ICSI), and the generation of sperm for ICSI requires surgery. In all cases of patients with symptoms of obstructive azoospermia and severe oligozoospermia recommended to conduct a preliminary analysis of microdeletion of AZF-region for the differential diagnosis and the possibility of ICSI. [6]. Given the progression of the disruption of spermatogenesis from oligozoospermia to azoospermia patients with AZFmicrodeletions should advise such patients received sperm cryopreservation [10].

According to recommendations of the European Association of Reproduction and Embryology (ESHRE) in diagnosing Y-chromosome microdeletions candidates for analysis are men, the concentration of sperm in the ejaculate which is $<5 \times 10^{6} / \mathrm{ml}[3]$.

Deletions of AZFa-and AZFb-subregions associated with the inability to produce mature germ cells, in contrast to the sub-region AZFc deletions, when there is a high probability of mature sperm. However, even with the use of reproductive technologies are at high risk of having a boy with $\mathrm{Y}$-microdeletions.
In our work, we set out to determine the frequency of deletions in the AZF locus in patients with idiopathic infertility.

Materials and methods. We observed 80 men with idiopathic infertility at the age of 19-40 years. All patients underwent clinical and urological examination: complete blood count, urinalysis, Wassermann, blood sugar, blood biochemical examination, hormonal examination (testosterone, LH, FSH, prolactin), karyotyping, ultrasound examination of the scrotum and prostate, microscopic and bacteriological study of semen, a study on sexually transmitted infections.

68 patients with the concentration of sperm in the ejaculate $<5 \times 10^{6} / \mathrm{ml}$ conducted a genetic blood test for the presence of deletions in the AZF locus Y-chromosome. Isolation and purification of DNA from whole venous blood passes through a standard method of precipitation of nucleic acids. For the analysis of the variations of the gene regions of AZF deletions specific DNA amplification was carried out in vitro [7, 8, 11, 12, 14].

Results. In the study of hormonal levels in patients showed no hormonal disorders, and the testosterone level was $13,45 \pm 6,35 \mathrm{nmol} / \mathrm{L}, \mathrm{LH}$ $17,25 \pm 6,25 \mathrm{IU} / \mathrm{L}$, FSH 9,0 $\pm 8,2 \mathrm{IU} / 1$, prolactin $710 \pm 640 \mathrm{mU} / 1$. Occupational sperm in the ejaculate averaged $14.9 \times 10^{6} \pm 14.9 \times 10^{6} / \mathrm{ml}$. In the study group of 68 patients with idiopathic infertility with the concentration of sperm in the ejaculate $<5 \times 10^{6} / \mathrm{ml}$, after the survey revealed deletions in the AZF locus in 6 patients (8.8\%) Many studies, including our own, indicate the important role of deletions in the locus AZF Y-chromosomes in the control of spermatogenesis in men.

Azoospermia factor is one of the most common causes of male infertility, which causes widespread study of this factor in recent years. Based on data from the world literature and our own observations, the necessity of research azoospermia factor for all men with azoospermia / oligozoospermia severe.

Conclusion. Determining the frequency of deletions in the AZF locus is an important tool for studying the causes of azoospermia / oligozoospermia severe male infertility.

\section{Список литературы}

1. Денисенко С.В., Дарий А.С., Кононенко М.И., Зерова-Любимова Т.Э. Генетика репродукции. К.: Ферзь-ТА, 2008. - С. 128-139.

2. Оценка качественных показателей эякулята у пациентов с бесплодием / И.И. Горпинченко, О.Д. Никитин, С.В. Базалицкая и др. // Здоровье мужчины. - 2012. - № 3(42). - C. 112-115.

3. A simple, low cost and non-invasive method for screening $Y$-chromosome microdeletions in infertile men / Aknin-Siefer I.E., Touraine R.L., Lejeune H. et al. // Hum. Reprod. - 2003. - N 18. P. 257-261. 
4. Divergent outcomes of intrachromosomal recombination of the human $Y$ chromosme: male infertility and recurrent polymorphism / Blanco P., Shlumkova M., Sargent C.A. et al. // J. Med. Genet. - 2000. P. 752-758.

5. Foresta C. Y chromosome and male infertility: Update, 2006. Csilla Krausz and Selene Degl'Innocenti // Frontiers in Bioscience. - 2006. - N 11. - P. 3049-3061.

6. Foresta C., Ferlin A., Gianaroli L., Dallapiccola B. Guidelines for the appropriate use of genetic tests in infertile couples // Eur. J. Hum. Genet. - 2002. - N 10. - P. 303-312.

7. Taq Start Antibody: "Hot start" PCR facilitated by a neutralizing monoclonal antibody directed against Taq DNA polymerase / Kellogg D.E., Rybalkin I., Chen S. er al. // Biotechniques. - 1994. N 16. - P. 1134-1137.

8. Kostiner D.R., Turek P.J., Reijo R.A. Male infertility analysis of the markers and genes on the $Y$ chromosome // Hum Reprod. - 1998. - N 13. - P. 3032-3038.

9. A high frequency of $Y$ chromosome deletions in males with nonidiopathic infertility / Krausz C., Quintana-Murci L., Barbaux S. et al. // J. Clin. Endocrinol. Metab. - 1999. - P. 3606-3612.

10. Krausz C., McElreavey K. Y chromosome and male infertility // Front. Biosci. - 1999. - N 4. P. $1-8$.

11. Amplification of cDNA ends based on template - switching effect and stepout PCR / Matz M., Shagin D., Bogdanova E. et al. // Nucleic Acids Res. - 1999. - N 27. - P. 1558-1560.

12. Laboratory guidelines for molecular diagnosis of Y-chromosomal microdeletion / Simoni M. et al. // Intern. J. Andrology. - 1999. - N 22. - P. 292-299.

13. Tiepolo L., Zuffardi $O$. Localisation of factors controlling spermatogenesis in nonfluorescent portion of the human chromosome Y long arm // Hum. Genet. - 1976. - N 34. - P. 119-124.

14. Human $Y$ chromosome azoospermia factors (AZF) mapped to different subregions in Yq11/ Vogt P.H., Edelmann A., Kirsh S. et al. // Hum. Mol. Genet. - 1996. - N 5. - P. 933-943.

\section{Реферат}

\section{AZF-ДЕЛЯЦІЯ - ОДНА 3 ГЕНЕТИЧНИХ ПРИЧИН ЧОЛОВІЧОГО БЕЗПЛІДДЯ}

\author{
В.П. Стусь, Л.Іे. Падалко, \\ М.Ю. Поліон
}

Можливості дослідження причин безпліддя у чоловіків значно розширилися завдяки розшифровці генома людини, секвенуванню Y-хромосоми і впровадженню сучасних молекулярних технологій в медичну практику. Нами проведено обстеження 80 чоловіків з ідіопатичним безпліддям, яке включало в себе загальноклінічне та урологічне дослідження: загальний аналіз крові, загальний аналіз сечі, реакція Вассермана, цукор крові, біохімічні обстеження крові, гормональне обстеження (тестостерон, ЛГ, ФСГ, пролактин), каріотипування, ультразвукове дослідження органів калитки і передміхурової залози, мікроскопічне і бактеріологічне дослідження еякуляту, дослідження на інфекції, які передаються статевим шляхом.

68 пацієнтам з концентрацією сперматозоїдів в еякуляті $<5 \times 10^{6} /$ мл проводилося генетичне дослідження крові на наявність делецій в AZF локусі Y-хромосоми. Виділення та очистка ДНК із цільної венозної крові проходила за допомогою стандартного методу осадження нук-

\section{Реферат}

\section{AZF-ДЕЛЯЦИЯ - ОДНА ИЗ ГЕНЕТИЧЕСКИХ ПРИЧИН МУЖСКОГО БЕСПЛОДИЯ}

\author{
В.П. Стусь, Л.И. Падалко, \\ Н.Ю. Полион
}

Возможности исследования причин бесплодия у мужчин значительно расширились благодаря расшифровке генома человека, секвенированию Y-хромосомы и внедрению современных молекулярных технологий в медицинскую практику. Нами проведено обследование 80 мужчин с идиопатическим бесплодием, которое включало в себя общеклиническое и урологическое исследование: общий анализ крови, общий анализ мочи, реакция Вассермана, сахар крови, биохимические обследование крови, гормональное обследование (тестостерон, ЛГ, ФСГ, пролактин), кариотипирование, ультразвуковое исследование органов мошонки и предстательной железы, микроскопическое и бактериологическое исследования эякулята, исследование на инфекции, передающиеся половым путем.

68 пациентам с концентрацией сперматозоидов в эякуляте $<5 \times 10^{6} /$ мл проводилось генетическое исследование крови на наличие делеций в AZF локусе Y-хромосомы. Выделение и 
леїнових кислот. Для аналізу варіацій делеції регіонів гена AZF проводилася специфічна ампліфікація ДНК in vitro. У досліджуваній групі (68 хворих) делеції в локусі AZF були виявлені у 6 пацієнтів $(8,8 \%)$.

Згідно з даними світової літератури і за результатами власних спостережень очевидною $€$ необхідність дослідження фактора азоосперміі всім чоловікам з азооспермією/олігозооспермією важкого ступеня.

Ключові слова: чоловіче безпліддя, azfделяція.

\section{Адреса для листування}

В.П. Стусь

E-mail: viktor.stus@gmail.com очистка ДНК из цельной венозной крови проходила с помощью стандартного метода осаждения нуклеиновых кислот. Для анализа вариаций делеции регионов гена AZF проводилась специфическая амплификация ДНК in vitro. В исследуемой группе (68 больных) делеции в локусе AZF были выявлены у 6 пациентов $(8,8 \%)$.

Согласно данным мировой литературы и по результатам собственных наблюдений очевидна необходимость исследования фактора азооспермии всем мужчинам с азооспермией/олигозооспермией тяжелой степени.

Ключевые слова: мужское бесплодие, azfделяция. 